\title{
Differences Between the 1992 and 1993 CABO Model Energy Codes
}

D. R. Conover

R. G. Lucas

January 1995

Prepared for the U.S. Department of Energy under Contract DE-AC06-76RLO 1830

Pacific Northwest Laboratory

Operated for the U.S. Department of Energy

by Battelle Memorial Institute 


\title{
DISCLAIMER
}

This report was prepared as an account of work sponsored by an agency of the United States Government. Neither the United States Government nor any agency thereof, nor Battelle Memorial institute, nor any of their employees, makes any warranty, expressed or implied, or assumes any legal liability or responsibility for the accuracy, completeness, or usefulness of any information, apparatus, product, or process disclosed, or represents that its use would not infringe privately owned rights. Reference herein to any specific commercial product, process, or service by trade name, trademark, manufacturer, or otherwise does not necessarily constitute or imply its endorsement, recommendation, or favoring by the United States Government or any agency thereof, or Battelle Memorial Institute. The views and opinions of authors expressed herein do not necessarily state or reflect those of the United States Government or any agency thereof.

\author{
PACIFIC NORTHWEST LABORATORY \\ operated by \\ BATTELLE MEMORIAL INSTITUTE \\ for the \\ UNITED STATES DEPARTMENT OF ENERGY \\ under Contract DE-ACO6-76RLO 1830
}

Printed in the United States of America

Available to DOE and DOE contractors from the

Office of Scientific and Technical Information, P.O. Box 62, Oak Ridge, TN 37831; prices available from (615) 576-8401. FTS 626-8401.

Available to the public from the National Technical Information Service, U.S. Department of Commerce, 5285 Port Royal Rd., Springfield, VA 22161. 


\section{DISCLAIMER}

Portions of this document may be illegible in electronic image products. Images are produced from the best available original document. 
Differences Between the 1992 and 1993 CABO Model Energy Codes

D. R. Conover

R. G. Lucas

January 1995

Prepared for

the U.S. Department of Energy

under Contract DE-AC06-76RLO 1830

Pacific Northwest Laboratory

Richland, Washington 99352 



\section{Foreword}

This report is one in a series of documents describing research activities in support of the U.S. Department of Energy (DOE) Building Energy Standards Program. The Pacific Northwest Laboratory (PNL) leads the program for DOE. The goal of the program is to develop and encourage the implementation of performance standards to achieve the maximum practicable energy efficiency in the design of new buildings. Such standards are required of DOE by Title III of the Energy Conservation and Production Act (42 USC 6831 et seq.) as amended by the Energy Policy Act of 1992 (EPAct, Public Law 102-486).

The program approach to meeting the goal is to initiate and manage individual research and standards and guidelines development efforts that are planned and conducted in cooperation with representatives from throughout the buildings community. Projects under way involve practicing architects and engineers, professional societies and code organizations, industry representatives, and researchers from the private sector and national laboratories. Research results and technical justifications for standards criteria are provided to standards development and model code organizations and to Federal, State, and local jurisdictions as a basis to update their codes and standards. This effort helps to ensure that building standards incorporate the latest research results to achieve maximum energy savings in new buildings, yet remain responsive to the needs of the affected professions, organizations, and jurisdictions. Our efforts also support the implementation, deployment, and use of energy-efficient codes and standards.

This report identifies the differences between the 1992 and 1993 editions of the Council of American Building Officials (CABO) Model Energy Code (MEC) and briefly highlights the technical and administrative impacts of these changes.

Readers with questions, comments, or suggestions about this document or the work it describes are encouraged to contact the author(s), program managers, or project managers.

Jeffrey A. Johnson

Building Energy Standards Program

Pacific Northwest Laboratory
Jean J. Boulin

Office of Codes and Standards

U.S. Department of Energy 



\section{Summary}

The Energy Policy Act of 1992 (EPAct, Public Law 102-486) requires the U.S. Department of Energy (DOE) to determine if changes to the Council of American Building Officials (CABO) 1992 Model Energy Code (MEC) (CABO 1992), published in the 1993 edition of the MEC (CABO 1993), will improve energy efficiency in residential buildings. The DOE has determined that the provisions in the 1993 MEC improve energy efficiency in residential buildings ${ }^{(a)}$ and has published a notice of this determination in the July 15, 1994 . Federal Register (59 FR 36173-76). Each state is required to certify whether their state building code meets or exceeds the 1993 MEC within two years of this notice. Because states must compare their codes to both the $1992 \mathrm{MEC}$ and the $1993 \mathrm{MEC}, \mathrm{DOE}$ expects considerable interest in the specific changes to the $1992 \mathrm{MEC}$ as published in the $1993 \mathrm{MEC}$ and their potential impact. Several states have already requested this information from DOE.

To help states and others identify and understand the impact of the changes to the 1992 MEC, DOE tasked the Pacific Northwest Laboratory (PNL) with identifying those changes and their impacts.

Most of the changes are minor. Some section numbers have changed in the 1993 MEC because provisions were added and deleted. Significant changes are listed below:

- The $1993 \mathrm{MEC}$ has more stringent multifamily wall $\mathrm{U}_{\mathrm{o}}$ value requirements at all heating degree-days (HDDs) and one- and two-family ceiling and wall requirements at low HDDs [Table 502.2.1].

- The 1993 MEC has new requirements for heating, ventilating, and air-conditioning (HVAC) equipment efficiencies, which are consistent with the National Appliance Energy Conservation Act of 1987 (Public Law 100-12) and updated voluntary consensus standards [Section 503].

- The $1993 \mathrm{MEC}$ has new requirements for duct insulation [Section 503.9.1].

- In the $1993 \mathrm{MEC}$, requirements for multifamily residential buildings over three stories in height and all nonresidential buildings (i.e., commercial buildings, including hotels and motels) appear only in Chapter 7, which simply adopts by reference ASHRAE/IES Standard 90.1-1989 (ASHRAE 1989). In the $1992 \mathrm{MEC}$, requirements for multifamily residential buildings over three stories in height and all nonresidential buildings were based on ANSI/ASHRAE/IES Standard 90A-1980 (ASHRAE 1980) and were interspersed within the MEC. Note that this change does not affect requirements for residential buildings three stories or less in height (i.e., residential buildings).

(a) Residential buildings are considered to include one- and two-family dwellings, townhouses, rowhouses, and multifamily residential structures less than or equal to three stories in height. All other buildings are considered commercial buildings (including hotels, motels, and high-rise multifamily buildings) for the purpose of this report. 



\section{Contents}

Foreword $\ldots \ldots \ldots \ldots \ldots \ldots \ldots \ldots \ldots \ldots \ldots \ldots \ldots \ldots \ldots \ldots \ldots$

Summary $\quad \ldots \ldots \ldots \ldots \ldots \ldots \ldots \ldots \ldots \ldots \ldots \ldots \ldots \ldots \ldots \ldots$

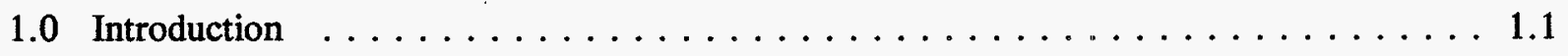

2.0 Changes to the 1992 MEC Contained in the 1993 MEC . . . . . . . . . . 2.1

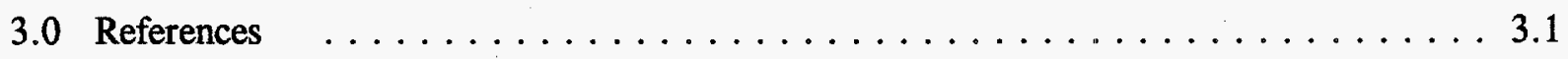




\subsection{Introduction}

The Energy Policy Act of 1992 (EPAct, Public Law 102-486) requires the U.S. Department of Energy (DOE) to determine if changes to the Council of American Building Officials (CABO) 1992 Model Energy Code (MEC) (CABO 1992), published in the 1993 edition of the MEC (CABO 1993), will improve energy efficiency in residential buildings. The DOE has determined that the provisions in the 1993 MEC improve energy efficiency in residential buildings ${ }^{(a)}$ and has published a notice of this determination in the July 15, 1994 Federal Register (59 FR 36173-76). Each state is required to certify whether their state building code meets or exceeds the 1993 MEC within two years of this notice. Because states must compare their codes to both the 1992 MEC and $1993 \mathrm{MEC}$, DOE expects considerable interest in the specific changes to the $1992 \mathrm{MEC}$ as published in the $1993 \mathrm{MEC}$ and their potential impact. Several states have already requested this information from DOE.

To help states and others identify and understand the impact of the changes to the $1992 \mathrm{MEC}$, the DOE tasked the Pacific Northwest Laboratory (PNL) with identifying those changes and their impacts.

Section 2.0 of this report describes each change to the 1992 MEC, published in the 1993 MEC, and its impact. Referenced publications are listed in Section 3.0.

(a) Residential buildings are considered to include one- and two-family dwellings, townhouses, rowhouses, and multifamily residential structures less than or equal to three stories in height. All other buildings are considered commercial buildings (including hotels, motels, and high-rise multifamily buildings) for the purpose of this report. 


\subsection{Changes to 1992 MEC Contained in 1993 MEC}

Table 2.1 describes the changes made to the 1992 MEC that are published in the 1993 MEC. Most of these changes are minor. Some section numbers have changed in the 1993 MEC because provisions were added or deleted. These numbering changes are not addressed in Table 2.1. To fully understand all changes, a copy of both the 1992 MEC and 1993 MEC is required. All changes are identified within the 1993 MEC by vertical lines and asterisks (see page iii of the 1993 MEC for further details).

Significant changes are listed below:

- The $1993 \mathrm{MEC}$ has more stringent multifamily wall $\mathrm{U}_{\mathrm{o}}$ value requirements at all heating degree-days (HDDs) and one- and two-family ceiling and wall requirements at low HDDs [Table 502.2.1].

- The 1993 MEC has new requirements for heating, ventilating, and air-conditioning (HVAC) equipment efficiencies, which are consistent with the National Appliance Energy Conservation Act of 1987 (Public Law 100-12) and updated voluntary consensus standards [Section 503].

- The $1993 \mathrm{MEC}$ has new requirements for duct insulation [Section 503.9.1].

- In the $1993 \mathrm{MEC}$, requirements for multifamily residential buildings over three stories in height and all hotels, motels, and nonresidential buildings (i.e., commercial buildings) appear only in Chapter 7, which simply adopts by reference ASHRAE/IES Standard 90.11989 (ASHRAE 1989). In the $1992 \mathrm{MEC}$, requirements for multifamily residential buildings over three stories in height and all nonresidential buildings were based on ANSI/ASHRAE/IES Standard 90A-1980 (ASHRAE 1980) and were interspersed within the MEC. Note that this change does not affect requirements for residential buildings three stories or less in height (i.e., residential buildings). 
Table 2.1. Changes to 1992 MEC Contained in 1993 MEC

\begin{tabular}{|c|c|c|}
\hline $\begin{array}{c}1993 \text { MEC } \\
\text { Section Number } \\
\text { (Unless Noted) }\end{array}$ & Description of Change & Impact \\
\hline 101.2 & $\begin{array}{l}\text { A reference to the new Chapter } 7 \text { on } \\
\text { buildings other than residential } \\
\text { buildings (i.e., commercial } \\
\text { buildings (a) is added and Chapters } \\
4,5 \text {, and } 6 \text { are redirected to apply to } \\
\text { only residential buildings. }{ }^{\text {(b) }}\end{array}$ & $\begin{array}{l}\text { In conjunction with other revisions, } \\
\text { eliminates provisions for buildings, } \\
\text { except for residential buildings, that } \\
\text { were based on } A N S I / A S H R A E / I E S \\
\text { Standard } 90 A-1980 \text { (ASHRAE 1980) } \\
\text { and certain equipment efficiency } \\
\text { provisions of ASHRAE/IES Standard } \\
90.1-1989 \text { (ASHRAE 1989) from the } \\
\text { body of the MEC. Solely references } \\
\text { ASHRAE/IES Standard } 90.1-1989 \text { for } \\
\text { these buildings. }\end{array}$ \\
\hline 101.3 & The new Chapter 7 is referenced. & See Section 101.2. \\
\hline $\begin{array}{l}101.3 .1 .1 \\
101.3 .1 .2\end{array}$ & $\begin{array}{l}\text { The description of buildings is added } \\
\text { to cover residential and other } \\
\text { buildings. }\end{array}$ & $\begin{array}{l}\text { Shows buildings to which Chapters } 4,5 \text {, } \\
\text { and } 6 \text { apply (residential buildings), and } \\
\text { buildings governed by Chapter } 7 \\
\text { (commercial buildings). }\end{array}$ \\
\hline 201.1 & $\begin{array}{l}\text { The definition of Annual fuel utiliza- } \\
\text { tion efficiency (AFUE) is added. }\end{array}$ & $\begin{array}{l}\text { Facilitates use of the term as applied in } \\
\text { the MEC as a descriptor of the efficiency } \\
\text { rating for fossil fuel-fired heating } \\
\text { equipment. }\end{array}$ \\
\hline 201.1 & $\begin{array}{l}\text { The definitions of Coefficient of } \\
\text { performance (COP) - cooling and } \\
\text { Coefficient of performance (COP) - } \\
\text { heat pump - heating are relocated to } \\
\text { this section. }\end{array}$ & $\begin{array}{l}\text { Has no impact. These definitions were } \\
\text { in Chapter } 5 \text { of the } 1992 \text { MEC. }\end{array}$ \\
\hline 201.1 & $\begin{array}{l}\text { The definition of Efficiency, HVAC } \\
\text { system is revised to specify output to } \\
\text { be used and that input and output be } \\
\text { in consistent units. }\end{array}$ & $\begin{array}{l}\text { Clarifies how to determine HVAC } \\
\text { system efficiency. }\end{array}$ \\
\hline 201.1 & $\begin{array}{l}\text { A reference to COP is added to the } \\
\text { definition for Energy efficiency ratio } \\
\text { (EER). }\end{array}$ & $\begin{array}{l}\text { Clarifies that an EER becomes a COP } \\
\text { when consistent units are used. }\end{array}$ \\
\hline
\end{tabular}

(a) Commercial buildings include hotels, motels, high-rise multifamily buildings and all other nonresidential buildings (see footnote $b$ ) for the purpose of this report.

(b) Residential buildings are considered to include one- and two-family dwellings, townhouses, rowhouses, and multifamily residential structures less than or equal to three stories in height. 
Table 2.1. (contd)

\begin{tabular}{|c|c|c|}
\hline $\begin{array}{c}1993 \mathrm{MEC} \\
\text { Section Number } \\
\text { (Unless Noted) }\end{array}$ & Description of Change & Impact \\
\hline 201.1 & $\begin{array}{l}\text { The definitions of Furnace, duct and } \\
\text { Furnace, warm air are added. }\end{array}$ & $\begin{array}{l}\text { Assists in distinguishing between } \\
\text { different furnace types to apply } \\
\text { efficiency requirements in the MEC. }\end{array}$ \\
\hline 201.1 & $\begin{array}{l}\text { A description of what constitutes } \\
\text { Group } \mathbf{R} \text { residential buildings is } \\
\text { relocated to this section from the body } \\
\text { of the } 1992 \text { MEC. }\end{array}$ & Has no impact. \\
\hline 201.1 & $\begin{array}{l}\text { A change in the state of a material is } \\
\text { added as a source of energy in the } \\
\text { definition of Heat. }\end{array}$ & Expands definition of heat. \\
\hline 201.1 & $\begin{array}{l}\text { The definition of Heating seasonal } \\
\text { performance factor (HSPF) is } \\
\text { added. }\end{array}$ & $\begin{array}{l}\text { Facilitates the use of a term used in the } \\
\text { MEC to specify heat pump equipment } \\
\text { efficiency. }\end{array}$ \\
\hline 201.1 & $\begin{array}{l}\text { In the definition of HVAC system, } \\
\text { the term "system" is replaced by the } \\
\text { term "equipment, distribution net- } \\
\text { work, and terminals." }\end{array}$ & $\begin{array}{l}\text { Clarifies what HVAC system provisions } \\
\text { apply to. }\end{array}$ \\
\hline 201.1 & $\begin{array}{l}\text { The definition of Integrated part- } \\
\text { load value (IPLV) is added. }\end{array}$ & $\begin{array}{l}\text { Facilitates the use of a term used in the } \\
\text { MEC to specify HVAC equipment } \\
\text { efficiency. }\end{array}$ \\
\hline 201.1 & $\begin{array}{l}\text { The definition of Overall thermal } \\
\text { transfer value (OTTV) is deleted. }\end{array}$ & $\begin{array}{l}\text { Has no impact because deleting } \\
\text { provisions for commercial buildings and } \\
\text { referencing } A S H R A E / I E S \text { Standard } 90.1- \\
1989 \text { eliminates the need for the term. }\end{array}$ \\
\hline 201.1 & $\begin{array}{l}\text { The definition of Packaged terminal } \\
\text { air conditioner (PTAC) is revised to } \\
\text { include heating capability and the wall } \\
\text { sleeve as part of the unit. }\end{array}$ & $\begin{array}{l}\text { Clarifies the application of PTAC } \\
\text { efficiency in the MEC. }\end{array}$ \\
\hline 201.1 & $\begin{array}{l}\text { The definition of Packaged terminal } \\
\text { heat pump (PTHP) is revised to indi- } \\
\text { cate a PTHP can provide heat. }\end{array}$ & $\begin{array}{l}\text { Clarifies the application of PTHP } \\
\text { efficiency criteria in the MEC. }\end{array}$ \\
\hline 201.1 & $\begin{array}{l}\text { The definition Nondepletable energy } \\
\text { sources in the } 1992 \text { MEC is renamed } \\
\text { Renewable energy sources. }\end{array}$ & Has no impact. \\
\hline 201.1 & $\begin{array}{l}\text { The definition of Residential build- } \\
\text { ings is added. }\end{array}$ & $\begin{array}{l}\text { Defines residential buildings for the } \\
\text { MEC. }\end{array}$ \\
\hline
\end{tabular}


Table 2.1. (contd)

\begin{tabular}{|c|c|c|}
\hline $\begin{array}{c}1993 \text { MEC } \\
\text { Section Number } \\
\text { (Unless Noted) }\end{array}$ & Description of Change & Impact \\
\hline 201.1 & $\begin{array}{l}\text { The definition of Seasonal energy } \\
\text { efficiency ratio (SEER) is added. }\end{array}$ & $\begin{array}{l}\text { Facilitates the use of a term used in the } \\
\text { MEC to specify HVAC equipment } \\
\text { efficiency in the cooling mode. }\end{array}$ \\
\hline 201.1 & $\begin{array}{l}\text { The definition of Shading coefficient } \\
\text { (SC) is deleted. }\end{array}$ & $\begin{array}{l}\text { Has no impact because deleting pro- } \\
\text { visions for commercial buildings and } \\
\text { referencing } A S H R A E / I E S \text { Standard } 90.1 \text { - } \\
1989 \text { eliminates the need for the term. }\end{array}$ \\
\hline 201.1 & $\begin{array}{l}\text { The definition of Slab-on-grade floor } \\
\text { insulation is added. }\end{array}$ & Has no impact. \\
\hline 201.1 & $\begin{array}{l}\text { The definitions of Water Heater, } \\
\text { Non-Storage and Water Heater, } \\
\text { Storage are added. }\end{array}$ & $\begin{array}{l}\text { Facilitate application of the water heater } \\
\text { efficiency requirements, which differ by } \\
\text { water heater type. }\end{array}$ \\
\hline 301.1 & $\begin{array}{l}\text { The scope of Chapter } 3 \text { is changed to } \\
\text { apply only to Group R residential } \\
\text { buildings. }\end{array}$ & See Section 101.2. \\
\hline 302.1 & $\begin{array}{l}\text { Degrees north latitude is deleted as an } \\
\text { exterior design condition. }\end{array}$ & $\begin{array}{l}\text { Has no impact because deleting } \\
\text { provisions for commercial buildings and } \\
\text { referencing } A S H R A E / I E S \text { Standard } 90.1 \text { - } \\
1989 \text { eliminates the need to designate } \\
\text { this value. }\end{array}$ \\
\hline 401.1 & $\begin{array}{l}\text { The scope of Chapter } 4 \text { is changed to } \\
\text { apply only to Group R residential } \\
\text { buildings. }\end{array}$ & See Section 101.2. \\
\hline 402.2 & $\begin{array}{l}\text { A provision that energy use at the site } \\
\text { shall be compared and that conversion } \\
\text { of energy sources shall be based on } 1 \\
\mathrm{kWh}=3,413 \mathrm{Btu} \text { is added. }\end{array}$ & $\begin{array}{l}\text { Reinforces that the energy comparison } \\
\text { only considers energy used at the } \\
\text { building and does not consider the } \\
\text { efficiency of generation, transmission, } \\
\text { and distribution of electric power and } \\
\text { other fuels prior to their delivery to the } \\
\text { site. }\end{array}$ \\
\hline 402.5 & $\begin{array}{l}\text { Commercial and industrial buildings } \\
\text { are deleted from the exception. }\end{array}$ & $\begin{array}{l}\text { Has no impact because the scope of } \\
\text { Chapter } 4 \text { is now only residential } \\
\text { buildings. }\end{array}$ \\
\hline 403 & $\begin{array}{l}\text { The term "nondepletable source } \\
\text { analysis" is changed to "renewable } \\
\text { energy source analysis." }\end{array}$ & Has no impact. \\
\hline
\end{tabular}


Table 2.1. (contd)

\begin{tabular}{|c|c|c|}
\hline $\begin{array}{c}1993 \text { MEC } \\
\text { Section Number } \\
\text { (Unless Noted) }\end{array}$ & Description of Change & Impact \\
\hline 403.2 & $\begin{array}{l}\text { The term "commercial structures" is } \\
\text { deleted from Exception } 1 \text {. Excep- } \\
\text { tion } 2 \text {, which applies to commercial, } \\
\text { institutional, and industrial structures, } \\
\text { is completely deleted. }\end{array}$ & Has no impact. See Section 402.5 . \\
\hline 501.1 & $\begin{array}{l}\text { The scope of Chapter } 5 \text { is changed to } \\
\text { apply only to Group } R \text { residential } \\
\text { buildings. }\end{array}$ & See Section 101.2. \\
\hline 501.1 & $\begin{array}{l}\text { Provisions requiring a building to } \\
\text { meet the more stringent of its heating } \\
\text { or cooling requirements are deleted. }\end{array}$ & $\begin{array}{l}\text { Has no impact because the code only } \\
\text { provides one set of requirements for } \\
\text { residential building exterior envelope } \\
\text { design. }\end{array}$ \\
\hline 502.1 .1 & $\begin{array}{l}\text { References to Table 502.3.1 are } \\
\text { deleted. }\end{array}$ & $\begin{array}{l}\text { Has no impact because the table has been } \\
\text { deleted and comparable provisions are } \\
\text { found in Chapter } 7 \text { for commercial } \\
\text { buildings. }\end{array}$ \\
\hline 502.2 & $\begin{array}{l}\text { Provisions defining Group } \mathrm{R} \text { resi- } \\
\text { dential buildings are deleted. }\end{array}$ & $\begin{array}{l}\text { Has no impact. See Sections 101.3.1.1 } \\
\text { and } 201 \text { where these same provisions } \\
\text { were relocated as a definition. }\end{array}$ \\
\hline $\begin{array}{l}502.3 \\
(1992 \text { edition })\end{array}$ & $\begin{array}{l}\text { All thermal envelope provisions are } \\
\text { deleted for buildings other than Group } \\
\text { R residential buildings. }\end{array}$ & See Section 101.2. \\
\hline 502.3 .2 & $\begin{array}{l}\text { The allowable air infiltration rates for } \\
\text { nonwood windows and doors are } \\
\text { changed. Separate requirements by } \\
\text { frame type (wood, aluminum, and } \\
\text { PVC) are added. Also, references are } \\
\text { added to industry window and door } \\
\text { construction standards. Requirements } \\
\text { for nonresidential doors are removed. }\end{array}$ & $\begin{array}{l}\text { Requirements for nonwood windows } \\
\text { are slightly less stringent in the } 1993 \\
\text { MEC than the } 1992 \text { MEC. Require- } \\
\text { ments for sliding doors are more } \\
\text { stringent. Changes in these allowable } \\
\text { air infiltration rates have an unclear } \\
\text { effect on total heating and cooling } \\
\text { energy use. }\end{array}$ \\
\hline 502.3 .3 & $\begin{array}{l}\text { Wall assemblies and sill-plates and } \\
\text { foundations are added as examples of } \\
\text { areas in the building envelope to be } \\
\text { sealed. Refers to openings in the } \\
\text { building envelope rather than listing } \\
\text { the envelope components. }\end{array}$ & $\begin{array}{l}\text { Has no impact. Consists of minor word- } \\
\text { ing changes that do not change the } \\
\text { general requirement to seal all joints in } \\
\text { the building envelope. }\end{array}$ \\
\hline
\end{tabular}


Table 2.1. (contd)

\begin{tabular}{|c|c|c|}
\hline $\begin{array}{c}1993 \text { MEC } \\
\text { Section Number } \\
\text { (Unless Noted) }\end{array}$ & Description of Change & Impact \\
\hline $\begin{array}{l}\text { Equations } 3 \text { and } \\
4 \text { (1992 Edition) }\end{array}$ & These equations are deleted. & $\begin{array}{l}\text { Has no impact because all provisions for } \\
\text { commercial buildings are covered by } \\
\text { reference to } A S H R A E / I E S \text { Standard } \\
90.1-1989 \text {; this eliminates the need for } \\
\text { these equations. }\end{array}$ \\
\hline 503.1 & $\begin{array}{l}\text { Hospitals, laboratories, and facilities } \\
\text { with open refrigerated display cases } \\
\text { are deleted from the exception. }\end{array}$ & $\begin{array}{l}\text { Has no impact because Chapter } 5 \text { now } \\
\text { only applies to Group R residential } \\
\text { buildings. }\end{array}$ \\
\hline 503.4 .1 .3 & $\begin{array}{l}\text { Provisions to address HVAC equip- } \\
\text { ment for which efficiency require- } \\
\text { ments are not given in the MEC are } \\
\text { added. }\end{array}$ & $\begin{array}{l}\text { Has no impact except to clarify that } \\
\text { equipment not included in the efficiency } \\
\text { tables can still be used and is } \\
\text { "unregulated." }\end{array}$ \\
\hline $\begin{array}{l}503.4 .2 \text { and } \\
\text { Tables } 503.4 .2 \mathrm{a} \\
\text { through } 503.4 .2 \mathrm{~d}\end{array}$ & $\begin{array}{l}\text { Electric-powered heat pump com- } \\
\text { ponent minimum efficiencies, test } \\
\text { procedures, and efficiency descriptors } \\
\text { based on } A N S I / A S H R A E / I E S \text { Standard } \\
90 A-1980 \text { are replaced with those } \\
\text { from } A S H R A E / I E S \text { Standard } 90.1- \\
1989 .\end{array}$ & $\begin{array}{l}\text { Provides consistency with current } \\
\text { standards and improves energy } \\
\text { efficiency. }\end{array}$ \\
\hline 503.4 .2 & $\begin{array}{l}\text { Efficiency level is referenced (as } \\
\text { specified in the table that provides } \\
\text { efficiencies) instead of COP. }\end{array}$ & $\begin{array}{l}\text { Has no impact except to refer to the } \\
\text { appropriate heat pump efficiency } \\
\text { descriptor. }\end{array}$ \\
\hline $\begin{array}{l}503.4 .2 .2 \\
\text { (1992 Edition) }\end{array}$ & $\begin{array}{l}\text { The description of "COP heating" is } \\
\text { deleted. }\end{array}$ & $\begin{array}{l}\text { Has no impact because the term was } \\
\text { added to the definitions chapter. }\end{array}$ \\
\hline $\begin{array}{l}503.4 .3 \text { and } \\
\text { Tables } 503.4 .3 \mathrm{a} \\
\text { through } 503.4 .3 \mathrm{c}\end{array}$ & $\begin{array}{l}\text { Fossil fuel-fired heating equipment } \\
\text { minimum efficiencies, test } \\
\text { procedures, and efficiency descriptors } \\
\text { based on } A N S I / A S H R A E / I E S \text { Standard } \\
90 A-1980 \text { are replaced with those } \\
\text { from } A S H R A E / I E S \text { Standard } 90.1- \\
1989 .\end{array}$ & $\begin{array}{l}\text { Provides consistency with current } \\
\text { standards and improves energy } \\
\text { efficiency. }\end{array}$ \\
\hline $\begin{array}{l}503.4 .5 \text { and } \\
\text { Tables } 503.4 .5 \mathrm{a} \\
\text { through } 503.4 .5 \mathrm{f}\end{array}$ & $\begin{array}{l}\text { Electric-powered HVAC equipment } \\
\text { minimum efficiencies in the cooling } \\
\text { mode, test procedures, and efficiency } \\
\text { descriptors based on } \\
\text { ANSI/ASHRAE/IES Standard } 90 A- \\
1980 \text { are replaced with those from } \\
\text { ASHRAE/IES Standard } 90.1-1989 \text {. }\end{array}$ & $\begin{array}{l}\text { Provides consistency with current } \\
\text { standards and improves energy } \\
\text { efficiency. }\end{array}$ \\
\hline
\end{tabular}


Table 2.1. (contd)

\begin{tabular}{|c|c|c|}
\hline $\begin{array}{c}1993 \text { MEC } \\
\text { Section Number } \\
\text { (Unless Noted) }\end{array}$ & Description of Change & Impact \\
\hline 503.4.5.1 & $\begin{array}{l}\text { Exemption for areas having open } \\
\text { refrigerated food displays, such as } \\
\text { supermarkets, is deleted. }\end{array}$ & $\begin{array}{l}\text { Has no impact because requirements } \\
\text { only apply to commercial buildings. }\end{array}$ \\
\hline $\begin{array}{l}503.4 .5 .2 \\
\text { (1992 Edition) }\end{array}$ & $\begin{array}{l}\text { The description of COP cooling is } \\
\text { deleted. }\end{array}$ & $\begin{array}{l}\text { Has no impact because the term was } \\
\text { added to the definitions chapter. }\end{array}$ \\
\hline 503.4 .6 & $\begin{array}{l}\text { Minimum-efficiency levels for water } \\
\text { chilling packages, electrically } \\
\text { operated, in the cooling mode based } \\
\text { on } A N S I / A S H R A E / I E S \text { Standard } 90 A- \\
1980 \text { are replaced with those from } \\
\text { ASHRAE/IES Standard } 90.1-1989 \text {. }\end{array}$ & $\begin{array}{l}\text { Provides consistency with current } \\
\text { standards and improves energy } \\
\text { efficiency. }\end{array}$ \\
\hline $\begin{array}{l}\text { 503.4.6.1 } \\
\text { (1992 Edition) }\end{array}$ & $\begin{array}{l}\text { The description of COP cooling is } \\
\text { deleted. }\end{array}$ & $\begin{array}{l}\text { Has no impact because the term was } \\
\text { added to the definitions chapter. }\end{array}$ \\
\hline $\begin{array}{l}503.4 .7 \\
\text { (1992 Edition) }\end{array}$ & $\begin{array}{l}\text { Minimum-efficiency provisions for } \\
\text { heat-operated cooling equipment } \\
\text { based on } A N S I / A S H R A E / I E S \text { Standard } \\
90 A-1980 \text { are deleted. }\end{array}$ & $\begin{array}{l}\text { Has no impact because the provided } \\
\text { minimurns were commensurate with the } \\
\text { achievable minimums for single-stage } \\
\text { equipment. }\end{array}$ \\
\hline $\begin{array}{l}503.8 .3 .3 \\
\text { (1992 Edition) }\end{array}$ & $\begin{array}{l}\text { The provisions for temperature con- } \\
\text { trol of separate zones that were } \\
\text { applicable to spaces other than dwell- } \\
\text { ing units are deleted and incorporated } \\
\text { into Section } 503.8 .3 .2 \text { of the } 1993 \\
\text { MEC where they apply to the non- } \\
\text { dwelling portion of multifamily } \\
\text { structures. }\end{array}$ & Has no impact. \\
\hline 503.9 & $\begin{array}{l}\text { The minimum insulation requirement, } \\
\text { based on temperature differential } \\
\text { inside/outside the duct, is replaced } \\
\text { with a prescriptive table of minimum } \\
\text { duct insulation R-values as a function } \\
\text { of climate. }\end{array}$ & $\begin{array}{l}\text { Results in more or less energy savings, } \\
\text { depending on climate and duct location. }\end{array}$ \\
\hline 503.10 & $\begin{array}{l}\text { References related to duct construc- } \\
\text { tion are updated and a reference to a } \\
\text { NAIMA standard for fibrous glass } \\
\text { duct construction is added. }\end{array}$ & $\begin{array}{l}\text { Results in the application of more cur- } \\
\text { rent standards. }\end{array}$ \\
\hline
\end{tabular}


Table 2.1. (contd)

\begin{tabular}{|c|c|c|}
\hline $\begin{array}{c}1993 \text { MEC } \\
\text { Section Number } \\
\text { (Unless Noted) }\end{array}$ & Description of Change & Impact \\
\hline 504.2 .2 & $\begin{array}{l}\text { Allowable heat loss from unfired hot- } \\
\text { water storage tanks is reduced and an } \\
\text { exception for larger tanks insulated to } \\
\text { a specified R-value is added. }\end{array}$ & Results in greater energy savings. \\
\hline 504.5 .2 & See Section 403. & Has no impact. \\
\hline 505.3 .3 .1 & $\begin{array}{l}\text { "Etc." in the list of building types and } \\
\text { the exception for theatrical and } \\
\text { audiovisual areas in the } 1992 \text { MEC } \\
\text { are deleted. }\end{array}$ & $\begin{array}{l}\text { Allows the exception to the electric } \\
\text { lighting power requirements to apply to } \\
\text { only a few specific building types. }\end{array}$ \\
\hline 601.1 & $\begin{array}{l}\text { The reference to nonresidential build- } \\
\text { ings is deleted. }\end{array}$ & Has no impact. See Section 101.2. \\
\hline 602.1 & $\begin{array}{l}\text { Provisions are added allowing the } \\
\text { designer to consider more innovative } \\
\text { design concepts beyond thermal mass. }\end{array}$ & $\begin{array}{l}\text { Provides more opportunity for the build- } \\
\text { ing official to approve innovative } \\
\text { designs. }\end{array}$ \\
\hline 602.2 .1 & $\begin{array}{l}\text { More charts are added for specific } \\
\text { glass } U \text {-values, from which an opaque } \\
\text { wall and wall } U_{0} \text { criterion can be } \\
\text { determined for a particular design. }\end{array}$ & $\begin{array}{l}\text { Provides greater flexibility of use and } \\
\text { accuracy in using Chapter } 6 \text { by present- } \\
\text { ing more charts corresponding to more } \\
\text { window U-values. }\end{array}$ \\
\hline $\begin{array}{l}602.2 .2 \\
602.2 .3 \\
602.2 .4 \\
602.2 .5 \\
602.2 .6\end{array}$ & $\begin{array}{l}\text { Reference to Table } 502.3 .1 \text { is deleted, } \\
\text { which is in the } 1992 \mathrm{MEC} \text { and covers } \\
\text { high-rise residential and all } \\
\text { commercial buildings. }\end{array}$ & Has no impact. Also see Section 101.2. \\
\hline 602.3 .2 & See Section 502.3.3. & See Section 502.3.3. \\
\hline 603.2 & $\begin{array}{l}\text { The presentation of all HVAC } \\
\text { equipment performance requirements } \\
\text { is deleted and the user is referred back } \\
\text { to Section } 503.4 \text { where the require- } \\
\text { ments are already presented. }\end{array}$ & $\begin{array}{l}\text { Has no impact except to eliminate } \\
\text { presenting the same requirements twice } \\
\text { in the MEC. }\end{array}$ \\
\hline 604.1 .2 .3 & See Section 403. & See Section 403. \\
\hline
\end{tabular}


Table 2.1. (contd)

\begin{tabular}{|c|c|c|}
\hline $\begin{array}{c}1993 \text { MEC } \\
\text { Section Number } \\
\text { (Unless Noted) }\end{array}$ & Description of Change & Impact \\
\hline Chapter 7 & $\begin{array}{l}\text { A new Chapter is added applying to } \\
\text { buildings other than Group R } \\
\text { buildings (i.e., other than one- and } \\
\text { two-family dwellings and multifamily } \\
\text { buildings three stories or less in } \\
\text { height). Chapter } 7 \text { adopts } A S H R A E / \\
\text { IES Standard } 90.1 .1989 \text { by reference. } \\
\text { The } 1992 \text { MEC contains the technical } \\
\text { provisions of } A N S I / A S H R A E / I E S \\
\text { Standard } 90 A-1980, \text { which are } \\
\text { replaced in Chapter } 7 \text { by } A S H R A E / I E S \\
\text { Standard } 90.1-1989 \text { provisions for } \\
\text { these buildings. Also see } \\
\text { Section } 101.2 \text {. }\end{array}$ & $\begin{array}{l}\text { See Section } 101.2 \text {. The impact on } \\
\text { energy use is that attributable to the } \\
\text { differences between } A N S I / A S H R A E / I E S \\
\text { Standard } 90 A-1980 \text { and } A S H R A E / I E S \\
\text { Standard } 90.1-1989 .\end{array}$ \\
\hline Chapter 8 & $\begin{array}{l}\text { Various referenced standards are } \\
\text { updated and other referenced } \\
\text { standards are added. }\end{array}$ & $\begin{array}{l}\text { The changes between different editions } \\
\text { of referenced standards are not reviewed } \\
\text { here. }\end{array}$ \\
\hline Figure No. 1 & $\begin{array}{l}\text { The maximum wall } U_{o} \text { for multi- } \\
\text { family residential buildings three } \\
\text { stories or less in height is reduced. } \\
\text { The maximum wall } U_{o} \text { for one- and } \\
\text { two-family residential buildings is } \\
\text { reduced in areas below } 2500 \text { HDD. }\end{array}$ & $\begin{array}{l}\text { Results in reduced heat loss/gain and } \\
\text { associated reduction in loads and energy } \\
\text { use. }\end{array}$ \\
\hline Figure No. 2 & $\begin{array}{l}\text { The maximum roof/ceiling } U_{o} \text { is } \\
\text { reduced in areas with HDD below } \\
3800 \text {. }\end{array}$ & $\begin{array}{l}\text { Results in reduced heat loss/gain and } \\
\text { associated reduction in loads and energy } \\
\text { use. }\end{array}$ \\
\hline
\end{tabular}




\subsection{References}

59 FR 36173-76. July 15, 1994. "Building Energy Standards Program: Updating State Building Codes Regarding Energy Efficiency." Notice. Federal Register.

American Society of Heating, Refrigerating and Air-Conditioning Engineers, Inc. (ASHRAE). 1980. ANSI/ASHRAE/IES Standard 90A-1980, "Energy Conservation in New Building Design." New York, New York.

American Society of Heating, Refrigerating and Air-Conditioning Engineers, Inc. (ASHRAE). 1989. ASHRAE/IES Standard 90.1-1989, "Energy Efficient Design of New Buildings Except Low-Rise Residential Buildings." Atlanta, Georgia.

Council of American Building Officials (CABO). 1992. Model Energy Code; 1992 Edition. Falls Church, Virginia.

Council of American Building Officials (CABO). 1993. Model Energy Code; 1993 Edition. Falls Church, Virginia.

Energy Conservation and Production Act. Public Law 94-385, 42 USC 6831 et seq., as amended.

Energy Policy Act of 1992 (EPAct). Public Law 102-486, 106 Stat 2776.

National Appliance Energy Conservation Act of 1987. Public Law 100-12, 42 USC 6201 et seq., as amended. 


\section{Distribution}

No. of

Copies

Offsite

12 DOE/Office of Scientific and Technical Information

\section{J.J. Boulin}

Office of Codes and Standards CE-43

U.S. Department of Energy 1000 Independence Avenue SW Washington, DC 20585

S.J. Turchen Office of Codes and Standards CE-43

U.S. Department of Energy 1000 Independence Avenue SW Washington, DC 20585

S.P. Walder

Office of Codes and Standards CE-43

U.S. Department of Energy 1000 Independence Avenue SW Washington, DC 20585
No. of

Copies

Onsite

DOE Richland Operations Office

D.D. Green

K8-50

83 Pacific Northwest Laboratory

J.L. Carlson, Program Files (55) K5-02

C.C. Conner (20)

D.R. Conover

K5-16

R.G. Lucas

BWO

Publishing Coordination

K5-16

Technical Report Files (5) 